\title{
Frants Buhl som gammeltestamentlig teolog 1
}

\author{
Professor, dr.theol. \\ Jesper Høgenhaven, Københavns Universitet
}

\begin{abstract}
Frants Peder William Buhl (1850-1932) is credited with introducing modern critical exegesis in a Danish theological context. This article attempts to track Buhl's theological concerns. Buhl saw his work as an academic theologian in close connection with the faith and life of the Christian church. In his earlier works he defends a conservative historical position, including a Mosaic origin for Deuteronomy. Later, he embraces basic insights promoted by Julius Wellhausen, and accepts Pentateuchal source criticism and a late date for the Priestly source as founded on valid historical arguments. Buhl retained an independent position with regard to Wellhausen, and remained a great admirer of the conservative scholar Frantz Delitzsch. As a biblical theologian, he worked out a perspective which assigns significant value to the biblical texts as witnesses to a divine revelation unfolding through the course of history, and maintained that historical research at a critical basis is essential to a proper theological understanding of the Old Testament scriptures.
\end{abstract}

Keywords: Old Testament theology - Buhl, Frants - Pentateuch - biblical criticism - biblical theology - canon of the Old Testament - Wellhausen, Julius - Delitzsch, Frantz

Frants Peder William Buhl (1850-1932) er i dansk teologis historie kendt som den gammeltestamentlige ekseget, der indførte den historisk-kritiske bibelforskning i Danmark, og som forsvarede "bibelkritikkens" ret og betydning over for dens modstandere. ${ }^{2}$ Min-

1. Tilegnet Niels Peter Lemche i venskab og taknemmelighed i anledning af hans fødselsdag. Ikke alene falder den på samme dato som Frants Buhls (6/9); men gennem sit omfattende og innovative eksegestiske forfatterskab har Niels Peter Lemche udvist et inspirerende engagement netop i spørgsmål, der knytter sig til gammeltestamentlig og bibelsk teologi.

2. En kortfattet og nuanceret fremstilling af Buhls indsats og position i forhold til diskussionerne om "bibelkritikken" findes i Københavns Universitet 1479-1979. Bind V: Det teologiske Fakultet, red. Leif Grane (København: G.E.C. Gad 1980), 442-448. En koncis levnedsbeskrivelse er Johannes Pedersen, "Buhl, Frants Peder William”, Dansk Biografisk Leksikon IV, red. Povl Engelstoft (København: J.H. Schultz Forlag 1934), 340-344. En kort beskrivelse fra Buhls hånd af sine studieår foreligger i: Indbydelsesskrift til Kjøbenhavns Universitets Aarsfest til Erindring om Kirkens Reformation (Kjøbenhavn: J.H. Schultz 1878), 96-97. Se også Knud 
dre opmærksomhed har eftertiden generelt viet Buhls position som gammeltestamentlig teolog og den sammenkædning af det teologiske arbejde - herunder den bibelske eksegese - med kirkens eller den kristne menigheds liv, som stod centralt i Buhls egen forstålse af sin indsats. Det er denne bibelteologiske side af Buhls arbejde, som skal trækkes frem i det følgende, hvor jeg vil forsøge at vise den indre forbindelse, der ifølge Buhl består imellem en fri og uhildet historisk betragtning af bibelteksterne på den ene side og forståelsen af teksterne som vidnesbyrd om en guddommelig åbenbaring på den anden.

Buhl, der blev teologisk kandidat i 1874, havde i København studeret Det Gamle Testamente hos Christen Hermansen (1806-1882) og semitiske sprog hos August F.M. van Mehren (1822-1907). Han havde desuden også lejlighed til at studere i Leipzig og høre Frantz Delitzsch (1813-1890) og Heinrich Leberecht Fleischer (1801-1888). Ikke mindst Delitzsch må have gjort et stort indtryk på Buhl, der livet igennem bevarede en dyb agtelse for denne forsker.

I 1880 blev Buhl docent og fra 1882 professor i teologi med Det Gamle Testamente som fagområde. I 1890 modtog han kaldelsen til at blive Delitzsch' efterfølger i Leipzig. Her virkede han frem til 1898, hvor han vendte tilbage til København, nu som efterfølger for van Mehren i professoratet i semitisk filologi. Det gammeltestamentlige professorat var i mellemtiden overtaget af Buhls efterfølger, J.C. Jacobsen (1862-1948).

Buhls arbejde havde international rækkevidde. Flere af hans bøger blev oversat til tysk og engelsk; og han fik blivende betydning ikke mindst i kraft af, at han forestod en gennemrevideret ny udgave af Wilhelm Gesenius' (1786-1842) hebraiske ordbog. I Danmark kom hans lærebøger - specielt Det israelitisk-jødiske Folks Historie og hans kommentarer til Esajas og Salmerne - til at præge flere generationer af teologer. ${ }^{3}$

Jeppesen, "Frants Buhl as an Old Testament Scholar: The Isaiah Commentary in Danish", Genesis, Isaiah and Psalms: A Festschrift to honour Professor John Emerton for his eightieth birthday, red. Katharine J. Dell m. fl., Supplements to Vetus Testamentum 135 (Leiden/Boston: Brill 2010), 153-162; Jesper Høgenhaven, "Biblical Scholarship in Northern Europe", Hebrew Bible/Old Testament: The History of its Interpretation. Volume III: From Modernism to Post-Modernism (The Nineteenth and Twentieth Centuries). Part 1: The Nineteenth Century - a Century of Modernism and Historicism, red. Magne Sæbø (Göttingen: Vandenhoeck \& Ruprecht 2013), 223243 (236-239). For Buhls bibliografi se J. C. Jacobsen, "Frants Buhl”, Teologisk Tidsskrift for den danske Folkekirke, 4. række, 6 (1925), 271-291; "Supplement til Fortegnelsen over Prof., Dr.phil. et theol. Frants Buhls literære Arbejder”, Teologisk Tidsskrift for den danske Folkekirke 5. rekke 4 (1933), 159-160.

3. Kaj Munk (Foraaret saa sagte kommer. Erindringer (København: Westermann 1944), 322) beskriver i sine erindringer, hvordan han under læsningen af Buhls historie blev inspireret til at kaste sig ud i affattelsen af skuespillet En Idealist om kong 
I forhold til den bibelkritik, som i løbet af det 19. århundrede var vokset frem særlig i Tyskland, stod det københavnske fakultet i perioden med Christen Hermansen som professor i Gammel Testamente som en bastion for relativt konservative synsmåder. På denne baggrund måtte Buhls introduktion af kildekritik inden for fortolkningen af Mosebøgerne virke som et nybrud. Det er dog bemærkelsesværdigt, at Buhl stedse indtog en uafhængig kritisk position og $\mathrm{fx}$ på ingen måde var en ukritisk discipel af Julius Wellhausen (18441918), hvis kildekritiske studier af Pentateuken og Israels historie fik banebrydende betydning for den gammeltestamentlige forskning i 1800 -tallets slutning. På væsentlige punkter tilsluttede Buhl sig ganske vist Wellhausens kritiske position: Han accepterede således, at Pentateuken måtte være sammensat af fire oprindeligt selvstændige kildeskrifter fra forskellige perioder. Samtidig forblev Buhl dog livet igennem - under fuld anerkendelse af den historiske undersøgelses, herunder kildekritikkens, saglige berettigelse - en selvstændig forsker med et skarpt blik for nuancer og med en udtalt modvilje mod alt for omfattende totalløsninger, der ikke lod nuancerne i det gammeltestamentlige tekstmateriale træde frem. Og der er endvidere ét væsentligt aspekt ved bibeleksegese i en teologisk kontekst, som Buhl vedblivende lagde vægt på: Udgangspunktet for teologien og den teologiske bibeleksegese er den kristne menighed, idet det er menighedens hellige skrifter, der tolkes. Det betyder ikke, at eksegesen får sine resultater foreskrevet; men den kristne menigheds synspunkt er ikke noget, eksegesen kan se bort fra.

\section{Buhls tidlige arbejde om Pentateuken}

Første gang Buhl tager selvstændig offentlig stilling til de kritiske teorier om Pentateuken, som Wellhausen og andre repræsenterede, er i en artikel fra 1878 om Femte Mosebogs affattelsestid og oprindelse. ${ }^{4}$ I dette tidlige arbejde indtager Buhl i udgangspunktet det samme konservative standpunkt som sine lærere ved det københavnske fa-

Herodes den Store: "Nu sad jeg altsaa i Buddinge med Examen et Par smaa Maaneder foran mig og repeterede Buhls Det jødiske Folks Historie og læste om Herodes den Store og stødte paa en parentetisk Beklagelse af, at Shakespeare ikke var faldet over dette Stof. Det gav et Ryk i mig. Det var, som om en Pegefinger løftede sig ud af Bogens Parentes og strakte sig mod mig i et: Du er Manden".

4. Frants Buhl, "Naar er Femte Mosebog affattet? (Indledning til Undersøgelser om Pentateuchens Oprindelse.)", Theologisk Tidsskrift (1878 (uden binddnummer)), 129-168, 194-227. 
kultet. Buhl går således kritisk til opfattelsen af Deuteronomium som et værk fra kong Josijas' tid, som en række forskere (bl.a. Wilhelm Martin Leberecht de Wette, Heinrich Ewald, Karl Heinrich Graf og Abraham Kuenen) argumenterede for. Imod denne position hævder Buhl forbindelsen imellem Femte Mosebog og Moses, idet han forsvarer skriftets påstand om at gengive Moses' afskedstale til Israels folk som i det væsentlige historisk. Hvis Femte Mosebog ikke i en vis forstand lader sig føre tilbage til Moses, ville der i Buhls øjne være tale om et pseudonymt skrift. Og det er bemærkelsesværdigt, i hvor høj grad Buhl her forstår spørgsmålet om pseudonymitet som et spørgsmål med fundamentale etiske dimensioner. Pseudonymitet er en form for bedrag, "falsk Forfatterangivelse" med Buhls udtryk:

At der existerer underskudte Skrifter er en Kjendsgerning, der ikke kan betvivles, men det hindrer ikke, at Antagelsen af en falsk Forfatterangivelse er forbundet med de allerstørste Vanskeligheder, og kun er mulig naar aldeles gjennemsigtige og uimodsigelige Grunde tale derfor, og - kunne vi være fristede til at tilføie - slet Intet taler derimod (Buhl 1878, 131).

Man kan naturligvis diskutere, om Deuteronomium egentlig kan kaldes et pseudonymt skrift, da det intetsteds af teksten selv fremgår, at Moses skulle være forfatteren; men for Buhl er skriftets henvisning til Moses som autoritetsfigur i sig selv afgørende. I Buhls øjne har spørgsmålet om pseudonymitet netop en ganske særlig vægt i forbindelse med et skrift som Deuteronomium, hvor brugen af Moses' navn ikke alene tjener det almene formål at forsyne et skrift med "den høie Alderdoms Ærværdighed” men tillige giver direkte guddommelig autoritet til en samling love. Buhl mener således, at tanken om et bedrag på dette punkt - at en anonym forfatter skulle have udgivet sit værk for at stamme fra Moses mod bedre vidende - ville være uhyre vanskeligt at forene med den etiske position, vi ellers møder i skriftet (Buhl 1878, 131-132).

Deuteronomiums oprindelse - skriftets "ægthed" - som et mosaisk skrift er for Buhl umiddelbart knyttet sammen med skriftets kanoniske stilling og værdi: "Saa vidt vi formaae at se, medfører her en Benægtelse af Authentien ogsaa en Benægtelse af Kanoniciteten" (Buhl 1878, 132). Buhl vier en stor del af artiklen til en detaljeret gendrivelse af den kritiske teori, der forbinder Deuteronomium med kong Josijas' reform af kulten i det 7. århundrede. I denne forbindelse viser hans kritiske gennemgang af de forskellige argumenter for en affattelse på kong Manasses tid op til kultreformen i øvrigt et skarpt blik for den vilkårlighed, som ofte kommer til at præge slutninger, 
der eksklusivt bygger på en historiserende tolkning af de fortællende skrifter i Det Gamle Testamente eller enkelte passager heri.

Forlader man den traditionelle Opfattelse, ligger endnu baade det hebraiske Sprogs og de religiøse Ideers Historie i den Grad i det usikkre, at enhver Fortolker lægger dem tilrette efter sin egen Smag, og udsætter sig for at bevæge sig i en stadig Cirkel (Buhl 1878, 149).

Den indvending, Buhl her rejser mod den samtidige kritiske forsknings metodiske forudsætninger, foregriber på en vis måde den senere tids vurdering: Faren for cirkelslutninger har unægtelig ligget nær i meget af den historisk-kritiske bibelforsknings arbejde. Man har typisk opereret med en bestemt rekonstruktion af den israelitiske religions historie. Rekonstruktionen bygger på en bestemt datering af de forskellige dele af Det Gamle Testamente; men denne datering har igen rekonstruktionen som sit udgangspunkt. ${ }^{5}$

Buhls egen kritiske gennemgang leder nu frem til et dobbelt resultat: Deuteronomium kan ikke, medgiver han, være nedskrevet af Moses' egen hånd. På den anden side taler al sandsynlighed for, "at Nedskriveren kun har haft Indflydelse paa Formen, og at derfor Indholdet er at betragte som reent mosaisk, saaledes som Bogen selv paastaar for de egentlige Loves Vedkommende" (Buhl 1878, 215). Der er med andre ord en lille åbning i Buhls position, idet et egentligt mosaisk forfatterskab som et resultat af den kritiske undersøgelse må afskrives. Det forhindrer ham dog ikke i at antage en direkte forbindelse imellem den lovtradition, der er indeholdt i skriftet, og Moses og hans tid. Buhl er således nået til den konklusion, at den kritiske videnskab i virkeligheden viser sandsynligheden af den traditionelle opfattelse af Deuteronomium som mosaisk, i det mindste i sit væsentlige indhold. Den endelige vished leverer nu ifølge Buhl "det religiøse Beviis":

Er kun Sandsynligheden for den traditionelle Opfattelse fastslaaet, træder det religiøse Beviis, eller om man vil, den religiøse Tilegnelse til og skaffer den Sikkerhed, der ikke kan naaes paa anden Maade (Buhl 1878, 216).

Buhls formulering her er af flere grunde bemærkelsesværdig. Den viser, i hvor høj grad Buhl forstår sit ærinde som apologetisk. "Sikkerhed", når det gælder de bibelske bøgers ægthed og troværdighed,

5. Denne fare for bestandige cirkelslutninger understreges af Niels Peter Lemche, Det Gamle Testamente mellem teologi og historie. Den historisk-kritiske bibelforsknings storhed og fald (København: Anis 2008), 137-138. 
er tydeligvis et vigtigt mål. Den sikkerhed, han henviser til, er nøje forbundet med det, han kalder "den religiøse Tilegnelse", et udtryk, der må dække over en subjektiv indstilling hos den enkelte. Det er dog ikke sådan, at den ønskede sikkerhed uden videre er identisk med denne subjektive tilegnelse. Hvis det var tilfældet, ville den kritiske efterprøvning af de traditionelle opfattelser af bibelteksternes alder og ophav og af argumenterne imod disse være overflødig. Buhl anerkender også, at spørgsmålet om bibelteksternes herkomst har en objektiv side, som er underlagt den kritiske forsknings prøvelse. Det er denne, der må levere sandsynligheden for den traditionelle opfattelse af Moseloven. Og den kritiske prøvning kommer, som citatet viser, i en vis principiel forstand først. Havde undersøgelsen således vist, at Deuteronomium intet kunne have med Moses' tid at gøre, ville det være nødvendigt - må vi gå ud fra, når vi læser Buhl her - at opgive den traditionelle forståelse af skriftet som "mosaisk".

\section{Buhls artikler fra 1880erne om Pentateuken}

I de følgende år vedbliver Buhl (der altså fra 1882 er professor i Det Gamle Testamente ved det københavnske fakultet) at vende tilbage til Pentateuk-kritikkens helt centrale spørgsmål om antagelse af kilder og disses affattelsestid og indbyrdes forhold. Hans position, hvad det rent saglige angår - oprindelse, affattelsestid, muligheden for at sondre mellem oprindeligt selvstændige kilder osv. - bevæger sig i denne periode i stadig mere kritisk retning.

I en artikel fra 1884 forsøger han at tegne et samlet billede af den gammeltestamentlige forsknings aktuelle situation. ${ }^{6}$

Er den "mosaiske Lov" - ialtfald efter sine væsentlige Bestanddele - Udgangspunktet for Israels Historie, eller er den Afslutningen deraf og kun Udgangspunktet for det degenererede Israel, for Jødedommen, som den udformede sig efter det babyloniske Fangenskab? - saaledes lyder det store Spørgsmaaal, der har sat saa megen Skarpsindighed og Lærdom i bevægelse (Buhl 1884, 325).

Det spørgsmål, Buhl her henviser til som det afgørende udgangspunkt for en omfattende diskussion imellem gammeltestamentlige forskere, afspejler grundtesen i Julius Wellhausens Prolegomena zur

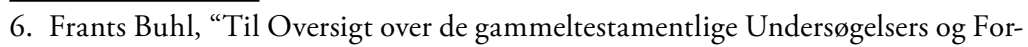
handlingers nuværende Standpunkt", Theologisk Tidsskrift for den danske Folkekirke 1 (1884), 325-342. 
Geschichte Israels (1878), at profeterne i det gamle Israel fra en religions- og litteraturhistorisk synsvinkel kommer før Moseloven. Loven er dermed ikke udgangspunktet for Israels men for jødedommens historie. ${ }^{7}$ Wellhausen gennemfører sin radikale ombytning af rækkefølgen - profeterne først og loven til sidst - på grundlag af en række kritiske studier af Pentateuken og de kildeskrifter fra forskellige perioder, som man mente, at den måtte være sammensat af. Denne kildekritik havde forskere som Wilhelm Vatke, Eduard Reuss, Karl Heinrich Graf og Abraham Kuenen i mangt og meget allerede tidligere udarbejdet. Wellhausen gav imidlertid den kritiske Pentateukteori dens klareste og mest konsekvente udtryk; og det er Wellhausens rekonstruktion af Israels historie og religon, som Buhl først og fremmest forholder sig til. ${ }^{8}$

Buhl mener nu at kunne konstatere, at der ikke alene er ved at være udbredt enighed om eksistensen af separate kildeskrifter bag den foreliggende Pentateuk, men at der tillige er ganske bred enighed om, at "Præsteskriftet" (P) må være den yngste kilde og ikke som tidligere antaget det ældste stof i Pentateuken.' Der er dog stadig væsentlige nuancer, når det gælder den absolutte datering: Wellhausen mente, at Deuteronomium hørte hjemme på kong Josijas' tid, og at P stammede fra eksiltiden, hvorimod Delitzsch daterede Deuteronomium til tiden imellem Salomo og profeten Esajas og P til den sidste del af kongetiden. Men at Delitzsch også havde antaget kritikernes relative datering af kilderne, viser ifølge Buhl rækkevidden af det nybrud, der har fundet sted i forskningen (Buhl 1884, 329).

Nok så vigtigt er det, at Delitzsch anser Præsteskriftets narrative indhold for historisk pålideligt, ligesom han fortsat vil hævde, at der i Pentateuken indgår mosaiske bestanddele ( $\mathrm{fx}$ de ti bud). Dommertiden er for Delitzsch ikke (som for Wellhausen) den oprindelige tilstand, som Israel langsomt har udviklet sig fra; men denne periode står snarere for et fald (med Buhls udtryk et "Tilbagefald") i forhold til den mosaiske tid. Og uagtet hvor mange forandringer der i enkelt-

7. Julius Wellhausen, Prolegomena zur Geschichte Israels, (Berlin: Georg Reimer ${ }^{5}$ 1899), 1-14. Buhls udtryk om den efterbibelske jødedom, "det degenererede Israel”, er naturligvis tidstypisk.

8. Se om den kritiske undersøgelse af Pentateuken i det 19. århundrede Thomas Römer, "'Higher Criticism'; The Historical and Literary-critical Approach - with Special reference to the Pentateuch", Sæbø (2013), 393-423; Rudolf Smend, "The Work of Abraham Kuenen and Julius Wellhausen”, Sæbø (2013), 424-453. Til Wellhausens helhedsopfattelse - og baggrunden herfor i hans stadium af Samuelsbøgerne - se også Karl William Weyde, "Studies on the Historical Boks - Including Their Relationship to the Pentateuch", Sæbø (2013), 521-555.

9. I perioden betegnede mange "Præsteskriftet" (P) som "grundskriftet". Andre gængse betegnelser for Præsteskriftet i perioden var "A" eller "den første elohist”. 
heder måtte være sket med Moselovens bogstav, udgør loven dog ikke desto mindre en enhed, der i alt væsentligt er bestemt af de grundtanker, som Moses har angivet. Dermed kan man meningsfuldt tale om loven som "Enhed og Helhed" til forskel fra den efterfølgende profeti (Buhl 1884, 330).

Delitzsch' position, som Buhl her ridser den op, svarer tydeligt nok i grundtræk til, hvad Buhl selv var nået frem til i forbindelse med sin undersøgelse af Deuteronomium: Indholdet var "mosaisk"; formen og udtrykket i den foreliggende tekst var derimod resultatet af en længere traditions- og redaktionsproces. Buhls udførlige henvisning til Delitzsch er da også helt i tråd med hans egen opfattelse. Værd at bemærke er det, at Buhl føjer følgende kommentar til sin gengivelse af Delitzsch' syn: "Dette er Menighedens Standpunkt, idet den indviklede Pentateuchkritik for den bliver et rent esoterisk Problem, som den hverken kan eller skal stræbe efter at beherske" (Buhl 1884, 330).

Buhl sætter med andre ord sin (og Delitzsch') formidlende forståelse af Moselovens historiske baggrund - indholdet går tilbage til Moses, formen har været genstand for en række forandringer gennem tiden - i direkte forbindelse med den kristne menigheds bibellæsning: I et kirkeligt perspektiv er det den fundamentale kontinuitet i Moseloven, der er det væsentlige; de finere detaljer i forbindelse med skrifternes formulering er noget, forskerne kan beskæftige sig med, uden at menighedens forhold til Bibelen eller den bibelske historie egentlig er berørt.

Denne position supplerer og underbygger Buhl med en argumentation for, at specielt de kultiske love i Præsteskriftet må afspejle ældre forhold, selv om selve den litterære komposition skulle afspejle en sen episode. I tilslutning til August Dillmann indvender Buhl (mod Wellhausen-skolen), at det er en absurd antagelse, at netop alle de kultiske love skulle være forfattet i det babyloniske eksil, hvor der ingen kult var. Hvad der blev indført ved Ezras reform efter eksilet har ikke været en samling helt nye, tidligere ukendte kultiske regler, men derimod en kodificering af ældre ritualer, men nu - under indtryk af den nye situation på den præstelige forfatters tid, hvor presset fra andre folkeslag var stærkere og mere mærkbart - med en særlig vægtlægning på skillelinjerne imellem jøder og hedninger (Buhl 1884, 331-334).

Vi kan altså notere os, at Buhl her i 1884, hvor han tydeligvis er i bevægelse i retning af en langt højere grad af tilslutning til den nyere Pentateuk-kritiks opfattelse af Mosebøgernes tilblivelseshistorie, helt udtrykkeligt ønsker at gøre fælles sag med en i bund og grund konservativt indstillet forsker som Delitzsch. Buhl giver i denne forbindelse også meget direkte udtryk for sin dybe beundring for Delitzsch, 
ikke mindst dennes evne og vilje til at ændre opfattelse under indtryk af tvingende saglige argumenter:

...navnlig maa det vække Beundring, at en Forfatter i en saa fremrykket Alder har haft Kraft til at optage en hel Række nye Synspunkter og til at modificere sin tidligere Opfattelse i saa stort et Omfang. Noget saadant sker kun efter en haard indre Kamp, især naar som her Standpunktet flyttes noget længere ud i negativ Retning, og vistnok kunde derfor den Ærbødighed for en subjectivt erkendt Sandhed, som Delitzsch paa denne Maade har lagt for Dagen, have gjort Krav paa en mindre brutal Behandling end den, der er bleven den til Del i Fortalen til Wellhausens Prolegomena (Buhl 1884, 329).

Buhl fremhæver således hæderligheden og sagligheden hos Delitzsch, træk, der lige præcis viser sig i villigheden til at skifte position trods den "indre kamp", som det utvivlsomt må have kostet. Samtidig finder Buhl anledning til at klandre Wellhausen for på arrogant ("brutal") vis at nedgøre Delitzsch' synspunkt.

I en dobbeltartikel (1885-1886) gør Buhl sin position op i forhold til den nyere Pentateuk-kritik, først og fremmest repræsenteret ved Wellhausen. ${ }^{10}$ Atter er det bemærkelsesværdigt, hvordan Buhl tager udgangspunkt i Frantz Delitzsch' studier over Pentateuken: I sine nyeste artikler har Delitzsch ændret sin position væsentligt i forhold til opfattelsen i hans Genesis-kommentar fra 1872. Igen tager Buhl denne bevægelighed som udtryk for forfatterens dybe engagement $\mathrm{i}$ stoffet:

For den, der ikke kjender de Skrifter, der have fremkaldt disse Afhandlinger, fremfor alt Wellhausens nu allerede berømte Prolegomena, maa unegtelig denne Forandring af Standpunkt tage sig ud som en højst paafaldende Bevægelse, der kunde synes at vidne om en pludselig, umotiveret og farlig Svaghed hos Forfatteren. Og dog vilde man derved gjøre Delitzsch en uforsvarlig Uret, da hans Udtalelser meget mere vare Frugter af en ganske usædvanlig Kraftanspændelse, der kjempede efter Fodfæste under det første overvældende Indtryk af det nye Angreb (Buhl 1885, 257).

Det er i denne sammenhæng - hvor Buhl som i 1884-artiklen ganske klart stiller sig på linje med Delitzsch - også værd at lægge mærke til den anvendte retorik. Wellhausens udspil kendetegnes som et angreb.

10. Frants Buhl, "Den nyeste Pentateuchkritiks Ret og Uret", Theologisk Tidsskrift for den danske Folkekirke 2 (1885), 256-282; "Den nyeste Pentateuchkritiks Ret og Uret II”, Theologisk Tidsskrift for den danske Folkekirke 3 (1886), 250-277. 
Det virker, som om Buhl her i et eller andet omfang genkender sin egen stilling i Delitzsch, som kæmper for at genvinde fodfæste under det nye angreb fra kritikken. Det militære billedsprog vender Buhl flere gange tilbage til. Den radikalt kritiske position udgør for Buhl et angreb; og overfor dette er det nødvendigt at gennemtænke den rette forsvarsstrategi:

Det gjelder om at se, hvad der skal og kan forsvares, og hvilke Sandheder der maa indrømmes. Kun ved aaben Anerkjendelse af disse sidste faar Forsvaret virkelig overbevisende Kraft, og der er kun Haab om at blive Kritiken overlegen ved at give Afkald paa Kunstgreb, der ere under al Kritik (Buhl 1885, 259).

Er Buhls retorik hentet fra slagmarken, hvor han ser sig selv som forsvarer af en bastion under fjendtligt angreb, er der, hvad den indholdsmæssige side af sagen angår, en bemærkelsesværdig åbenhed og fleksibilitet over hans linje. Buhl slår til lyd for en åben anerkendelse af de "sandheder", som kritikken har fremført, og som må indrømmes uden forbehold, fordi de er velbegrundede. Efter sammenhængen at dømme tænker Buhl her i første række på kildesondringen og fordelingen af Pentateuk-kilderne på forskellige faser af Israels historie. Her er det for Buhl afgørende, at det er teksterne selv, der leder til erkendelsen af kildesondringens nødvendighed og uundgåelighed (Buhl 1885, 265).

Når det gælder indsigter, som giver sig af et grundigt studium af teksterne, er Buhl da også rede til at indrømme den nyere kritik dens ubestridelige ret: at den har tjent til at fremkalde "en sandere og mere historisk Anskuelse af Lovens Stilling i den forexilske Tid" (Buhl 1886, 250). Denne sagligt begrundede anerkendelse betyder dog ikke, at Buhl er parat til at overtage Wellhausens positioner i deres helhed. Buhls kritiske modsvar drejer sig helt overordnet om Wellhausen-skolens udstrakte brug af argumentum e silentio: Når de gammeltestamentlige tekster tier om et eller andet fænomen eller forhold, mener man herfra uden videre at kunne slutte, at det pågældende fænomen eller forhold ikke eksisterede på disse teksters tid. Her peger Buhl på, at Det Gamle Testamente kun indeholder et lille begrænset udvalg af kilder til hele Israels historie. ${ }^{11}$ Det er derfor i Buhls øjne ikke noget afgørende bevis imod de præstelige offerloves eksistens i føreksilsk tid, at der ikke findes udtrykkelige henvisninger

11. Buhl nævner som et eksempel, at Jeremias slet ikke er nævnt i Kongebøgerne. Var Jeremias' Bog ikke overleveret, og havde Jeremias alene været omtalt i en notits i Krønikebøgerne, ville den moderne kritik givetvis have afskrevet ham som uhistorisk (Buhl 1886, 254). 
til disse love i den fortællende eller profetiske litteratur. Buhl er i det hele taget skeptisk over for den "nykritiske skoles" tilbøjelighed til at tænke i drastiske modsætninger: Wellhausen forstår lovene i de enkelte kildeskrifter som "successive, udtømmende og autoriserede Udtryk for de historisk giældende Lovforhold” (Buhl 1886, 272). De senere af disse lovsamlinger er blevet indført med det formål at erstatte og fortrænge den eller de tidligere gældende. Dette scenario finder Buhl usandsynligt; for det bliver herudfra uhyre vanskeligt at forstå den sammenredigering af kilderne, som dog må have fundet sted. Langt mere nærliggende er det at forestille sig en højere grad af kontinuitet, hvor Præsteskriftets kultiske lovgivning fx i stort omfang afspejler kultisk praksis længe før eksilet.

I forbindelse med spørgsmålet om Præsteskriftets alder går Buhl også i rette med Wellhausen for dennes subjektive og værdiladede domme over teksterne. Buhl fremhæver, hvordan vurderingen af $\mathrm{P}$ har skiftet kolossalt: Han citerer Heinrich Ewalds begejstrede beskrivelse af "das Buch der Ursprünge", som denne fortolker priser for skriftets fylde, klarhed og rolige gennemskuelighed. Sådan var synet på den præstelige forfatter for mindre end en generation siden. ${ }^{12} \mathrm{Nu}$ er det imidlertid den "herlige Jehovist", der har fortolkerens gunst og vækker begejstring, medens man udtaler sig nedsættende og negativt om det præstelige skrift, som "navnlig hos Wellhausen skildres paa en saa haanende og nedsættende Maade, at allerede dette kan forklare den Uvilje og Forargelse, som hans Prolegomena har vakt i mange Kredse" (Buhl 1885, 274). ${ }^{13}$

Noget afgørende nyt ved Wellhausens position er ifølge Buhl dens karakter af radikal helhedsløsning. Her møder man nemlig op med "en positiv udformet Totalopfattelse af det israelitiske Folks Udvikling, hvor hver Enkelthed synes at finde sin harmonisk bestemte

12. Buhl $(1885,273)$ citerer Heinrich Ewald, Geschichte des Volkes Israel I (Göttingen: In der Dieterichschen Buchhandlung 1864), 137-138. Det er tankevækkende at sammenligne Ewalds karakteristik af den præstelige forfatters stil med senere eksegeters indstilling: "Die darstellung hat eine von der wärme des theilnehmenden gefühls fast üppig überfliessende fülle, klarheit und ruhige durchsichtigkeit, welche um den gedanken nach allen seiten vollendethinzustellen auch leichte wiederholung nicht scheut und sich oft in einem fast dichterischen ebenmasse der glieder erst erschöpft".

13. Buhl henviser her til kapitlet om P i Wellhausens Prolegomena ("Durch diese Vorliebe für unfruchtbare Namen und Zahlen und technische Beschreibungen kommt der Priestercodex auf eine Linie zu stehn mit der Chronik und der übrigen Literatur des Judentums, welche mit der künstlichen Wiederbelebung der alten Tradition sich abgiebt" (Wellhausen (1899), 356). Se til den tidstypiske negative vurdering af $\mathrm{P}$ også Hans Jørgen Lundager Jensen, "Drabet på P. 1. del: Efterskrift til Wellhausens Prolegomena”, Fønix 18 (1994), 130-153; "Drabet på P. 2. del: Gunkels Einleitung”, Fønix 18 (1994), 224-251. 
Plads, og hvor alle de mange Gaader, som man i lange Tider beskjeftigede sig med, pludselig synes at faa deres fuldstændige Løsning" (Buhl 1885, 257). Netop denne side af Wellhausen-skolens position at der præsenteres en sammenhængende totalløsning - er efter Buhls mening med til at gøre den attraktiv for mange. Buhl henviser således til, at den "nyere Pentateuk-kritik" har vundet en hel række dygtige yngre teologer som tilhængere, blandt dem også flere, der ønsker at hævde Det Gamle Testamentes karakter af åbenbaringsbog. ${ }^{14}$ Dette kan for Buhl kun hænge sammen med, at kritikken rent faktisk påviser problemer og vanskeligheder, som fordrer en løsning, og som man ikke længere kan ignorere. Det eneste forudsigelige resultat, dersom disse vanskeligheder negligeres, er, at "alle, der tragte efter en dybere Tilegnelse", vil slutte sig til den nyeste kritiks løsning (som Buhl kalder en "Overhuggen af Knuden" (ibid.)).

Buhls retorik i denne forbindelse er sigende: Wellhausen-skolens kritiske position fremstår - i kraft af sin karakter af totalløsning med en vis forførende og i den forstand farlig attraktion. Buhl gør sig således en teoretisk overvejelse over denne radikale bibelkritiks muligheder for at vinde indpas i en dansk kontekst: Når kritikken har kunnet samle så mange tilhængere i udlandet, er det nærliggende, at det samme vil ske i Danmark, "hvis den blev fremsat med Talent og med Kjendskab til de mange forviklede Enkeltheder, hvoraf Pentateuchproblemet er sammensat - en Mulighed, der, hvad Dag det skal være, kan blive til Virkelighed" (ibid.).

Det er uden videre klart, at Buhl betragter dette perspektiv som lidet ønskværdigt. Nok så væsentligt er det, at hans baggrund for den vurdering først og fremmest er saglig og indholdsmæssig og altså ikke taktisk eller kirkepolitisk. Den wellhausenske model er i Buhls øjne lige præcis problematisk, fordi den giver indtryk af en så høj grad af sikkerhed, et træk, som den i øvrigt deler med den traditionelle ukritiske opfattelse af Pentateuken:

Idet vi nu saaledes ikke formaa at se en virkelig Løsning af Pentateuchens Gaader i den moderne Pentateuch-Kritik, knytte vi dertil den Bemærkning, at det overhovedet efter vor Formening aldrig vil lykkes fuldstændig at give en saadan Løsning deraf som den, Kritiken har tilstræbt, der har præcise og fyldestgjørende Svar paa rede Haand overfor alle Enkeltheder. Aabenbart er det netop dette Skin, der har skaffet den moderne Pentateuchkritik en saa forbausende Udbredelse; den kappes

14. Buhl (1885, 257-258) nævner som eksempel Friedrich Eduard König (Der Offenbarungsbegriff des Alten Testaments (Leipzig: J. C. Hinrichs'sche Buchhandlung 1882); Die Hauptprobleme der altisraelitischen Religionsgeschichte gegenüber den Entwicklungstheoretikern beleuchtet (Leipzig: J. C. Hinrichs'sche Buchhandlung 1884)). 
i saa Henseende med den traditionelle, rent antikritiske Opfattelse af Pentateuchen, idet den mener sig istand til med Bestemthed at angive Oprindelsen og Sammenhængen ved enhver selv den ubetydeligste Enkelthed (Buhl 1886, 272).

Det afgørende problem ved Wellhausen-modellen er med andre ord sagligt: Denne helhedstolkning repræsenterer et alt for unuanceret og forenklet forsøg på at få alle genstridige data til at falde på plads og kappes dermed i virkeligheden med den traditionelle antikritiske position. Den må derfor afvises og modvirkes, ikke primært fordi den er uantagelig i et kirkeligt perspektiv, men fordi den for en videnskabelig bedømmelse ikke holder. Men i øvrigt er der i Buhls forståelse ikke nogen modsætning her imellem den kristne menigheds interesse og den videnskabelige søgen efter sandhed. Det er således netop den wellhausenske models uholdbarhed fra et kritisk videnskabeligt synspunkt, der gør den ubrugelig i et kirkeligt perspektiv.

\section{Det Gamle Testamente og den kristne tro}

Der er for Buhl en indre overensstemmelse imellem den historiskkritiske betragtning af bibelteksterne og teksternes teologiske betydning. I artiklen fra 1885 går han ind på nogle mere principielle betragtninger over den kristne tros forhold til Det Gamle Testmente, som han betegner som "et mere middelbart Forhold" (Buhl 1885, 259).

På dette punkt er der en vigtig forskel imellem Det Gamle og Det Nye Testamente. Den kristne tro står nemlig i et direkte forhold til det, der fortælles i Det Nye Testamente, eller i hvert fald til det væsentlige i evangeliernes beretning om Jesus Kristus. Når der rettes angreb på Det Nye Testamente eller "den evangeliske historie", bliver striden derfor ifølge Buhl meget hurtigt til et personligt religiøst spørgsmål, hvor den afgørende instans bliver det umiddelbart personlige forhold til "det hellige Kristusbillede, som Evangelierne give", og hvor man til syvende og sidst træffer en personlig afgørelse, om man vil bøje sig for evangeliernes Kristusskikkelse, eller man vil forvandle den til en rent menneskelig skikkelse.

For Det Gamle Testamentes vedkommende er forholdet et andet, da dette

betegner Aabenbaringen paa et historisk trin, som vi som Kristne ere hævede over, og som vi ikke kunne fordybe os i, uden at Bjergprædikens 
“der er sagt til de Gamle - men jeg siger Eder" klinger for vore Ører. Kun forsaavidt Kristus vidner om sig selv, at han er den gamle Pagts Opfyldelse, forsaavidt altsaa den gamle Pagts Historie er en profetisk Historie, komme vi i et virkeligt personligt Forhold dertil, medens dette aftager i samme Grad som Gjenstandens profetiske Character træder tilbage (Buhl 1885, 260).

Den kristne tros forhold til de gammeltestamentlige skrifter og den åbenbaring, som de vidner om, er med andre ord et forskudt eller med Buhls udtryk "middelbart" forhold, der er formidlet gennem Det Nye Testamentes tolkning af det gammeltestamentlige vidnesbyrd. Det Nye Testamente er opfyldelsen af den gamle pagt, som dermed får karakter af en "profetisk Historie"; men det er tydeligvis ikke alt i Det Gamle Testamente, der uden videre er "profetisk" i denne forstand. Som bjergprædikenens modstilling af, hvad der i sin tid blev sagt til de gamle, og hvad Kristus nu siger, i Buhls læsning tydeligt viser, er der også sider af Det Gamle Testamente, som Kristus har ophævet eller i hvert fald relativeret. Og dermed bliver det nødvendigt at skelne inden for Det Gamle Testamente imellem det, der er "profetisk Historie" i den forstand, at det peger frem mod opfyldelsen i Kristus, og det, der ikke er.

Dette forskudte eller "middelbare" forhold, hvori den kristne står til Det Gamle Testamente, er for Buhl på en og samme tid en vanskelighed for forsvaret af Det Gamle Testamente og en stor lettelse. På den ene side gør dette "middelbare" forhold og den differentiering, det fordrer, forsvaret til en mere kompliceret og nuanceret sag. På den anden side befrier det også forhandlingerne om en række punkter, der ikke berører de kristnes tro på umiddelbar måde, fra en byrde (Buhl 1885, 260).

Når det drejer sig om Pentateuk-kritikken og de spørgsmål, der drejer sig om kildeskrifterne bag Mosebøgerne og deres indbyrdes alder osv., er der i virkeligheden netop tale om sådanne punkter, der kun har indirekte betydning for den kristne tro. Det, som Buhl kalder "den profetiske Side af Historien", er nemlig forholdsvis uberørt af dette opgør. Også kritikerne (Wellhausen-skolen) betragter den profetiske fortæller af urhistorien (J) som et tidligt skrift og priser i øvrigt dettes forfatter i høje toner. Det stof, som kritikerne flytter ned til en sen epoke, er det kultiske lovstof, som er uden større betydning $i$ en kristen sammenhæng. Faktisk taler også flere udsagn i Det Nye Testamente (Gal 3,19-20; Matt 19,8) for, at Moseloven er en historisk størrelse, der også undervejs i overleveringen kan have ændret sig under indtryk af skiftende situationer og hensyn (Buhl 1885, 260-261). 
Bag ved striden om den moderne Pentateuk-teori ligger der imidlertid en kontrovers, der stikker dybere, og som i virkeligheden drejer sig om den israelitiske religions karakter eller, for at blive i Buhls udtryksmåde, Det Gamle Testamentes karakter af åbenbaring. Kritikken ses nemlig som udtryk for "en ren naturlig Evolutionstheoris Anvendelse paa den israelitiske Religion" (Buhl 1885, 261). Men denne opfattelse - at Pentateuk-kritikken er farlig, fordi den tilskriver Moseloven en "naturlig" evolution uden at anerkende nogen guddommelig åbenbaring - beror i virkeligheden på en illusion. Kritikerne mener ganske vist, at de ved at rykke hele forestillingen om en førprofetisk tid op og overføre den til Israels seneste periode, har ryddet grunden til en ny bygning, der rejser sig på naturlig vis i kraft af en gradvis evolution fra "en almindelig Naturreligions Grundlag til den senere profetiske Højde” (Buhl 1885, 262). Men, påpeger Buhl, reelt fører denne forskydning i tid ikke til nogen bedre eller mere indlysende forklaring på den israelitiske religions opståen end den traditionelle opfattelse. "Man kan optage alle den nykritiske Skoles Resultater og alligevel kommer man ikke Forklaringen af den israelitiske Religions Oprindelse et Skridt nærmere" (ibid.).

Det afgørende er nemlig for Buhl, at der består et modsætningsforhold imellem den gammeltestamentlige religion på den ene side og enhver naturreligion på den anden. Derfor bliver det hverken mere eller mindre forståeligt, at profeterne skulle have skabt Israels særlige religionsform, end at den skulle stamme fra Moses. Kontrasten er den samme; og denne kontrast forbliver i grunden lige vanskelig at forklare uanset, hvordan man tidsfæster de enkelte dele af Det Gamle Testamente:

Man kan derfor uden Overdrivelse sige, at hvis Striden var endt med en ubetinget Sejr for den nye Pentateuchkritik, saa vilde dette ikke have forandret vor Opfattelse af den israelitiske Religions Aabenbaringscharacter og dybeste Oprindelse, saa lidt som Kristendommens Forhistorie derved vilde være blevet omstyrtet - hvor vanskeligt det i andre Henseender kunde være at tilegne sig en saadan Omvæltning af den overleverede Fremstilling af den gamle Pagts Historie (Buhl 1885, 262-263).

Her er der i virkeligheden tale om et generalangreb på Wellhausenskolens grundlæggende tankegang, der vil gøre profeterne i kongetidens Israel og Juda (og altså ikke Moses i et tidligt tidsrum af Israels historie) til de egentlige opfindere af den særlige gammeltestamentlige religion. Buhls hovedindvending er vel at mærke empirisk og historisk funderet: For Buhl er det en dokumenterbar kendsgerning, at den israelitiske religion skiller sig markant ud fra "naturreligionerne" 
i Israels omverden. Det er denne modsætning, der ifølge Buhl gør det ikke alene plausibelt men nødvendigt at fastholde forestillingen om den israelitiske religion som byggende på en guddommelig åbenbaring.

\section{Den historiske kritik og de bibelske skrifters værdi og betydning}

Buhl er således i 1885 nået til den slutning, at antagelsen af forskellige kildeskrifter bag Pentateukens foreliggende tekst er en uundgåelig slutning, som teksterne selv støtter. Der ligger imidlertid også ifølge Buhl et vigtigt apologetisk aspekt $\mathrm{i}$ kildesondringen, når først man har erkendt dens berettigelse og uundgåelighed. Hvis man nemlig vil fastholde, at Mosebøgerne skulle være en enkelt forfatters værk, bliver de "bestandige unødige Gjentagelser og endnu mere de uformidlede Modsætninger og Forskjelligeheder" i teksten et vidnesbyrd om denne forfatters ubehjælpsomhed og forvirring (Buhl 1885, 266). Er Mosebøgerne derimod resultatet af en varsom sammenstilling af forskellige oprindelig uafhængige kildeskrifter, vidner de ikke-ophævede modsætninger tværtimod om redaktorens skønsomhed og troskab mod de kilder, han benytter:

Men hvad der maa dadles hos en enkelt Forfatter, det bliver til Ære for den, der sammenstiller forskjellige Kilder, da det vidner om den Samvittighedsfuldhed og Troskab, hvormed han har gjengivet Brudstykkerne af de forskjellige Fortællere (Buhl 1885, 267).

Herved bliver den historiske kritik altså i virkeligheden leverandør af et gedigent forsvar for de gammeltestamentlige teksters værdi og rette betydning. Dette er nu i det hele taget en kongstanke hos Buhl: Den historiske forståelse af teksterne er så langt fra at udgøre et angreb på disses værdi, at den tværtimod leder til en dybere og mere ægte sans for skrifternes egentlige betydning.

Dette synspunkt udbygger og understreger Buhl i lejlighedsskriftet fra 1895 om den gammeltestamentlige kritiks berettigelse og betydning. ${ }^{15}$ Hans vigtigste eksempel er her Daniels Bog, som den histo-

15. Frants Buhl, Til Vejledning $i$ de gammeltestamentlige Undersøgelser. Et Lejlighedsskrift (Kjøbenhavn: Gyldendalske Boghandels Forlag 1895). Spørgsmålet om Daniels Bog spillede en ganske central rolle i tidens debat om "bibelkritikken". Christian Ditlef-Nielsen viede en hel monografi til at gendrive argumentet om, at det aramæiske i Daniel måtte være sent (Christian Ditlef-Nielsen, Danielsbo- 
riske kritik betragter som et skrift fra Makkabæertiden (midten af 2. årh. f.Kr.), medens den traditionelle opfattelse anså skriftet som stammende fra det babyloniske eksils tid i overensstemmelse med dets egen angivelige tidsramme. Buhl mener, at den kritiske (sene) datering af Daniels Bog giver et langt dybere indblik i skriftets betydning og åndelige rigdom, end den traditionelle opfattelse (Buhl 1895, 99).

Her gør Buhl dog en vigtig bemærkning: Det er nemlig ikke sådan, at det apologetiske ærinde skal have lov til at styre fortolkningen af de gammeltestamentlige tekster. Det styrende element må alene være hensynet til den sandhed, som det videnskabelige arbejde skal tjene så godt som muligt.

Men selv om den rigtigere Opfattelse af Bogens Character og Oprindelse ikke ydede en saadan positiv Vinding, saa vilde vi dog være ubetinget forpligtede til at give Sandheden Æren, saasandt det, som man træffende har kaldt videnskabelig Samvittighed, er noget langt Ædlere og med Kristendommens Aand langt nærmere beslægtet end alle Forsøg paa at fastholde en nedarvet Anskuelse ved Hjælp af Fortielser eller uridderlige Forsøg paa at spille Striden over paa det personlig religiøse Omraade (Buhl 1895, 99-100).

\section{Jødedommen og kirkens kanon}

I sin bog fra 1885 om den gammeltestamentlige kanondannelse og tekstoverleveringens historie giver Buhl udtryk for det synspunkt, at jøderne er den egentlige autoritet til at afgøre, hvad der hører med til kanon. ${ }^{16}$

Israels Folk, hvem den gammeltestamentlige Aabenbaring var blevet betroet, og hvis Livsopgave det var at bevare den ublandet og uforstyrret, er i Virkeligheden de retmæssig competente Dommere til at afgjøre, i hvilke Skrifter denne Aabenbaring fremtræder rent og uden fremmede og modificerende Elementer (Buhl 1885b, 53).

Ganske vist kan det fra et historisk synspunkt være vanskeligt og ind imellem umuligt at finde frem til de kriterier, der i sin tid lå til

gens Alde (København: G.E.C. Gad 1899)). Til periodens debat se generelt Grane (1980, se note 1).

16. Frants Buhl, Den gammeltestamentlige Skriftoverlevering (Kjøbenhavn: Gyldendalske Boghandels Forlag 1885b). 
grund for den ene eller anden konkrete afgørelse om inklusion i eller eksklusion fra kanon: At fx Prædikerens eller Esters Bog er med i den jødiske kanon men ikke Første Makkabæerbog, kan forekomme ejendommeligt; ikke desto mindre må vi ifølge Buhl "anerkjende Palæstinensernes Kanonsbestemmelser som den eneste Autoritet, der sætter os istand til at afgjøre, hvad der er et rent Udtryk for den gamle Pagts Indhold og hvad ikke" (Buhl 1885b, 53).

Her vender Buhl tilbage til bestemmelsen af den kristne menigheds forhold til Det Gamle Testamente som et "middelbart" forhold: Det drejer sig netop ikke om at gå "umiddelbart" til de enkelte skrifter i kanon - Buhl mener fx, at det er en sådan umiddelbar betragtning, der hos "et kraftigt og selvstændigt religiøst Gemyt" som Luther nødvendigvis må føre til nedsættende domme over enkelte af skrifterne (som Esters Bog). Buhl uddyber sin opfattelse ved at skelne imellem Det Gamle Testamente som udtryk for en "forberedende Religion" - en synsmåde, han lægger afstand til - og som udtryk for "en forberedende Aabenbaring". Forskellen ligger først og fremmest i det historiske: Det Gamle Testamente er ikke en forberedende religion, "der i jævn og uafbrudt Stigen fører op til et afsluttende Højdepunkt”. Det Gamle Testamente er derimod en forberedende åbenbaring, "der efter at have culmineret begynder at synke og opløse sig, forat det derigjennem maatte blive klart, at den var en ufuldkommen Form, der var bestemt til under stærke brydninger at vige Pladsen for det ny og fuldkomne, som skulde komme" (Buhl 1885b, 54).

De seneste dele af Det Gamle Testamente er således for Buhl - ligesom i øvrigt også for Wellhausen - udtryk for en form for nedadgående linje eller forfaldstendens. At denne begyndende opløsning eller nedgangslinje rent faktisk kommer til udtryk i de kanoniske skrifter selv, nedsætter nu efter Buhls opfattelse netop ikke disses værdi for forståelsen af den gamle pagts væsen og betydning. Tværtimod er - synes han at mene - just dette aspekt ved den gamle pagts åndshistorie af væsentlig betydning. Dette syn hænger sammen med, at den "forberedende Aabenbaring" i Buhls øjne er uløseligt knyttet til åndshistorien: Åbenbaringen er ikke primært eller eksklusivt knyttet til teksterne men fuldt så meget til det liv, som de vidner om.

Buhl beskriver den udvikling inden for den senere del af kanon, som der hentydes til, som en form for spaltning i jødedommen selv:

Den gamle Pagts sidste Tider vise os ikke blot Spirerne til den Jødedom, der anerkjendte Kristus, men ogsaa til den, der klamrede sig fast til det gamle og afviste dets Fuldkommengjørelse i Kristendommen (Buhl 1885b, 54). 
Der er således ikke en men to hovedlinjer i Det Gamle Testamente ifølge Buhl, en, der peger frem mod den nye pagt i Kristus, og en anden, der fortsætter i den farisæisk-rabbinske jødedom. Men netop tilstedeværelsen af begge disse linjer siger nu noget vigtigt om kompleksiteten i den gamle pagts historie, som den er bevidnet i Det Gamle Testamente:

\begin{abstract}
Alt dette kommer tilorde i de yngste af de Skrifter, som Palæstinenserne anerkjendte som tro Udtryk for den gamle Pagts Aandsliv, hvorfor disse Skrifters Betydning indenfor den gammeltestamentlige Skriftsamling kun lader sig paavise ved en middelbar historisk Betragtning, der formaar at tildele de enkelte Dele deres Plads indenfor det store, mangeartede Hele (Buhl 1885b, 54).
\end{abstract}

Buhl er, som formuleringen i det sidste citat viser, her tilbage ved sin kongstanke, at den "middelbare historiske betragtning" af Det Gamle Testamente er den afgørende nøgle til den rette forstålse. Her mødes det historiske og det teologiske perspektiv i Buhls optik: Det Gamle Testamente må forstås historisk for at give teologisk mening. Det er således konkret kun muligt at forstå betydningen af de yngste skrifter i Det Gamle Testamente - som fx Prædikerens Bog, Esters bog og Daniels Bog - gennem en historisk betragtning, der lader disse skrifter fremstå som vidnesbyrd om den tid, de er blevet til i, og om den udvikling, jødedommen på den tid var inde i. Den historisk funderede forståalse er med andre ord den vigtigste nøgle til at forstå Det Gamle Testamente i dets kompleksitet. Og denne forstålse er vel at mærke netop nødvendig, hvis Det Gamle Testamente skal give mening $\mathrm{i}$ en teologisk sammenhæng eller give mening som kanonisk skriftsamling for den kristne menighed. Det centrale i denne historiske forstålse af Det Gamle Testamente er at "faa et tro og ægte Billede af den gamle Pagts Aabenbaring med dens ejendommelige Udviklingsgang og af de Former, som det derved fremkaldte Liv antog" (Buhl 1885b, 55).

Dette tro og ægte billede fremgår for Buhl alene af de kanoniske, dvs. de af den palæstinensiske jødedom anerkendte, skrifter. Det synes nærliggende at forstå Buhls synspunkt på den måde, at netop udvælgelsen og afgrænsningen af den palæstinensiske jødiske kanon rent historisk udtrykker den betydning, som disse skrifter havde vundet for "det derved fremkaldte Liv". Den palæstinensiske jødiske menighed fandt i netop disse tekster sit livsgrundlag; og derved blev det netop denne skriftsamling, der kom til at præge det levede liv. Derfor er det for Buhl alene disse skrifter, som giver et sandt billede af den 
gamle pagts profetiske betydning "som Forudforkyndelse af Messias i Ord og Begivenheder" (ibid.).

Den særlige betydning, som Buhl tillægger den palæstinensiske jødiske kanon, indebærer også, at den kristne menighed bør anderkende og overtage kanons tredeling i loven, profeterne og skrifterne (Buhl 1885b, 56). Denne tredeling, som også Det Nye Testamente forudsætter og udtrykkeligt støtter, er nemlig ifølge Buhl forudsætningen for at forstå de enkelte skrifters rette plads og funktion i helheden. Buhl gennemfører da også denne tredeling af Det Gamle Testamente i sin oversættelse, der udkom i $1910 .{ }^{17}$

\section{Historiens betydning}

Til grund for Buhls forståelse af Det Gamle Testamente som kanonisk skrift ligger en opfattelse af historien som et afgørende element i Guds åbenbaring. Dette grundsyn forklarer Buhl i kort sammenhængende form i sin bog fra 1894 om de messianske forjættelser i Det Gamle Testamente. ${ }^{18}$ Der er ifølge Buhl en organisk uløselig sammenhæng imellem profeternes forkyndelse og den tid og de forhold, som de taler ind i. Det viser sig i de enkelte profeters individuelle menneskelige særpræg, som kendetegner de udsagn, de har efterladt sig. Denne menneskelige prægning af den profetiske forkyndelse samtidig med, at profeterne er sig bevidst, at de viderebringer det ord fra Gud, som de har fået givet, altså er formidlere af en guddommelig åbenbaring - sammenholder Buhl med inkarnationen:

Ligesom den guddommelige Logos ikke fremtraadte utilhyllet blandt Menneskene, men som Gudmenneske, saaledes forkyndte Profeterne ikke det guddommelige Ord som umiddelbart Ord af Gud, men som gudmenneskeligt Ord, d.e. præget og bestemt ved deres menneskelige Individualitet (Buhl 1894, 22).

Det enkelte menneske er ifølge Buhl "et Barn af sin Tid" og har sin nærmeste opgave i forhold til sin egen generation. Profeterne i Det Gamle Testamente har da også først og fremmest haft deres egen tid

17. Det gamle Testamente oversat under Medvirkning af Prof. theol. J.C. Jacobsen $i$ København, Pastor lic. theol. Martensen-Larsen i København, Professsor Dr. Michelet $i$ Kristiania og Cand.theol. Johannes Pedersen af Professor Dr. Fr. Bubl (København/ Kristiania: Gyldendalske Boghandel Nordisk Forlag 1910).

18. Frants Buhl, De messianske Forjattelser i Det Gamle Testament (Kjøbenhavn: Gyldendalske Boghandels Forlag 1894). 
for øje. Til gengæld har de været af den klare opfattelse, at Guds endegyldige indgriben, Herrens dag eller historiens afslutning var ganske nært forestånde og ville indtræffe i deres egen levetid. Således tænker forfatteren til Esajas 40-55, at den messianske herlighed indtræder samtidig med folkets hjemvenden fra det babyloniske eksil, medens Haggaj forventer den noget senere men dog i Zerubabels levetid. Buhl skelner her imellem et rent historisk og et absolut eskatologisk element i profeternes forkyndelse. De tidshistoriske forudsigelser gik ofte i opfyldelse på det konkrete plan: Nord- og Sydriget gik virkelig under, som profeterne havde forudsagt; og Deuterojesaja fik ret i, at de bortførte kunne vende hjem under Kyros. Derimod gik den eskatologiske forventning i arv fra generation til generation, idet historien stadig dementerede profeternes forventning om messiastidens og de forudgående katastrofers komme. Denne bestandige udsættelse førte dog ikke til nogen svækkelse af profeternes håb:

Derfor gik den med de tidshistoriske Forudsigelser sammenknyttede eskatologiske Forventning i Arv fra den ene Profet til den anden og beviste derved sin Selvstændighed og sin tidsovervindende EvighedsKraft, men stadig saaledes, at den efterfølgende Profet var ligesaa sikkert overtydet om Frelsens nære Komme som hans Forgjængere (Buhl 1894, 25-26).

Det er nu netop forbindelsen imellem de eskatologiske forventninger og det konkrete tidshistoriske stof, der ifølge Buhl har ledt mange nyere fortolkere til at skelne skarpt, så det er de evige religiøse grundtanker, der er det blivende i profeternes forkyndelse. Kristus og den kristne kirke er i denne optik ikke så meget opfyldelsen af profetierne som kulminationen på en religiøs udvikling (Buhl 1894, 27). Buhl vil derimod ikke skelne imellem evigt og tidsbestemt på denne måde, men hævder, at forbindelsen imellem profeternes "evig gyldige Tanker" og deres tidshistoriske forudsigelser

ikke betegner en hæmmende Forening af det Uensartede, men at der er et inderligt Slægtskab mellem dem, saa at de historiske Former trods deres Skiften og stadige Selvopløsning, dog betegner den uundværlige Legemliggjørelse for de profetiske Tanker, indtil disse endelig faa deres sande Legeme i Kristus og hans Kirke (Buhl 1894, 28).

Der er således en form for inkarnatorisk begrundet forbindelse imellem det guddommeligt åbenbarede indhold i Det Gamle Testamente og dettes tidshistoriske skikkelse. Buhl udfolder denne tanke ved at bestemme selve den gammeltestamentlige historie som profeti, for- 
billede eller typologisk historie. Han henviser til, at fortidige begivenheder allerede inden for Det Gamle Testamente selv bruges som forbilleder på det, der forventes, samtidig med, at det forventede bestandig overgår det tidligere. Det hænger sammen med, at Israel bestandig stræber mod virkeliggørelsen af et ideal, som er givet fra Moses' grundlæggelse af "et Samfund, der udelukkende skulde søge sin Frelse hos Jahve, og som ikke skulde kjende nogen anden Lov end hans hellige Vilje" (Buhl 1894, 30). Buhl betoner, at forventningen hos israelitterne om en virkeliggørelse af dette ideal ikke så meget føltes som et krav men snarere som "en af en mægtig Troskraft baaren Forvisning” (ibid., 31). Forventningen svækkes da heller ikke ved folkets fald og fjernhed fra idealet; tværtimod træder håbet om, at Jahve selv vil fuldende sit værk netop klarest frem under sådanne forhold. Ifølge Buhl sker den endelige virkelig- eller legemliggørelse af den gamle pagts ideal i Kristus og hans værk; og dermed indeholder profetierne - og, må man forstå, den gammeltestamentlige historie i det hele taget - ikke blot abstrakte religiøse tanker men virkelige forjættelser om Kristus (ibid., 32).

Med denne understregning af historien som "profetisk Historie" er Buhl tydeligt i slægt med en hovedstrømning i det 19. århundredes teologiske læsning af Det Gamle Testamente, der tilkender historien en primær betydning som åbenbaringens medium. ${ }^{19}$ For Buhl bliver der dermed en dyb overensstemmelse imellem den historisk-kritiske undersøgelse af Det Gamle Testamente og teologiens - og den kristne menigheds - spørgen efter teksternes profetiske vidnesbyrd om den gamle pagt som en foreløbig åbenbaring, der skal fuldendes i Kristus. Til denne overensstemmelse svarer det dybe slægtskab, som Buhl ser imellem den historisk-kritiske videnskabs sandhedskriterium og kristendommens forpligtelse på sandheden. Den historiske kritik i dens "rene" form - hvor det virkelig er sandheden, der spørges efter, og ikke bestemte teologiske eller anti-teologiske dagsordener, der søges fremmet - er dermed i pagt med den kristne menigheds behov for oplysning af Bibelen, selv om det ikke er alt, hvad den historiske undersøgelse beskæftiger sig med, der har nogen umiddelbar eller direkte relevans for menighedens forhold til teksterne.

Som bibelsk teolog står Buhl med andre ord i forlængelse af en lang tradition, der fremhæver historiens centrale betydning som det ydre udtryk for Guds forberedende åbenbaring. Hvad der især kendetegner Buhls position, er hans uforbeholdne anerkendelse af den

19. I bred forstand kan Buhl siges at videreføre elementer af den frelseshistoriske tænkning hos eksegeter som Carl Friedrich Keil og Delitzsch, ligesom man kan tale om et overordnet slægskab med den frelseshistoriske tilgang hos Carl Paul Caspari. Jf. Høgenhaven (2013), 229-234 (Se note 1). 
kritiske undersøgelses ret og egenværdi som en stræben efter sandhed i sin egen ret. Denne forpligtelse på sandheden ser Buhl som væsensbeslægtet med kristendommens sandhedsbegreb. Med denne accentuering kan Buhl siges at tegne en ny udformning af det historisk orienterede paradigme inden for bibelforskningen. 